А.Б. Скорик

Харківський начіональний університет Повітряних Сил ім. І. Кожедуба, Харків

\title{
МЕТОД АДАПТИВНОГО ПРОСТОРОВО-ЧАСОВОГО СИНТЕЗУ СТРУКТУРИ ДАТА-ЦЕНТРИЧНОЇ ЗРС. МОДЕЛЬ ЦИКЛУ БОЙОВОЇ РОБОТИ ЗРС НА ОСНОВІ ВИКОРИСТАННЯ МОДИФІКОВАНОÏ ПЕТЛІ ООDА
}

В статі піднімаються питання розбудови теорії дата-цеентричних операцій (DCO) на основі розробки методу адаптивного просторово-часового синтезу структури дата-центричної ЗРС. Даний метод розглядається як форма реалізації головних концептів DCO: метаморфізму $i$ 4D екстенціоналізму датацентричних систем-систем. Пропонується при описі бойової роботи ЗРС використовувати модифіковану модель петлі ОODA. Модифікація здійснюється шляхом введення фази синтезу і зміни змісту фази "орієнтація”. Цикл бойової роботи дата-иеентичної ЗРС представляється як череда вкладених петель OODSA. Розглядається методика використання рівнянь Ланчестера для аналітичної оцінки ефективності бойового застосування ЗРС.

Ключові слова: Дж. Бойд, ЗРС, метаморфізм, рівняння Ланчестера, очінка ефективності, системасистем, теорія дата-ијентричної операції, цүикл бойової роботи, 4D-екстенціоналізм, OODA, OODSA.

\section{Вступ}

Постановка проблеми. В основі теорії датацентричної операції (Data-Centric Operations) [1] лежать концепти метаморфізму - мінливості і гнучкого розвитку (variability \& agile development) i 4D екстенціоналізму дата-центричних систем-систем.

Під метаморфізмом розуміється адаптивний просторово-часовий синтез і реконфігурація структури дата-центричної системи-систем (DSoS), що забезпечує DSoS найбільшу ефективність проведення операції в конкретних умовах [2-3].

Для випадку ведення протиповітряного бою метаморфізм проявляється в тому, що при порівнянній інформованості повітряно-космічних сил противника і систем зенітного ракетного прикриття, перші мають значно більші маневрені можливості, другі, маючи значно меншу рухливість, парирують цю здатність противника здійснюючи маневр вогнем, для чого відповідно до циклу стрільби (циклу Бойда) постійно перебудовують свою просторовочасову структуру [2].

В основі концепції Бойда лежить використання циклічних процесів OODA - Observe (Спостереження) - Orient (Орієнтування) - Decide (Рішення) - Act (Дія) [4]. Сукупність постулатів даної концепції носить відкритий характер і допускає розширення або скорочення з урахуванням конкретизації сфери розглянутих задач.

Відповідно до ідей Дж. Бойда будь-яка діяльність у військовій сфері 3 певним ступенем наближення може бути представлена у вигляді моделі OODA. У ряді офіційних доктринальних документів MO США петля OODA розглядається в якості єдиної типової моделі циклу прийняття рішень для сис- тем командування і управління (C2 systems), як своїх військ, так і військ противника [7-8].

Будучи льотчиком винищувачем, Дж. Бойд абсолютно вірно описав петлю управління для технічних систем (винищувач - це технічна система). Однак цей підхід $є$ недостатнім для аналізу функціонування сучасних мережеємних систем-систем ОВТ. Слід відзначити, що використання циклів Бойда при аналізі протиповітряного бою (ППБ) як операції [2], що здійснюється дата-центричною ЗРС [3], потребує внесення суттєвих змін в існуючу модель циклу OODA.

Одними з головних питань при розробці методу адаптивного просторово-часового синтезу структури дата-центричної ЗРС є зміна просторової структури ЗРС в залежності від функцій, що виконуються на різних фазах циклу бойової роботи. Таким чином, проблема розробки моделі циклу бойової роботи ЗРС як дата-центричної системи-систем є актуальною.

Аналіз останніх досліджень і публікацій. Оcнови теорії дата-центричних операцій розглянуті в роботах [1-3]. У роботі [4] зібрані матеріали відносно поглядів полковника Бойда на створення і розвиток процесів OODA. У роботах [5-6] акцентується увага на зв'язку поглядів Бойда 3 концепцією мережецентричної війни. Взаємозв'язок процесів OODA i алгоритмів прийняття рішень у системах командування i управління $\mathrm{C}_{2}$ розглянуто в роботах [7-8]. Загальні основи теорії Бойда розглянуто в [9]. Зв'язок процесів OODA з теорією прийняття рішень органами військового управління розглянуто в [10]. Використання рівнянь Ланчестера для оцінки ефективності бойових дій наведено в роботах [11-12]. 
Мета роботи. Метою статті є розбудова теорії дата-центричних операцій на основі розробки моделі циклу бойової роботи ЗРС, що використовується як складова методу адаптивного просторовочасового синтезу структури дата-центричної ЗРС; аналіз існуючої моделі OODA і їі модифікація для забезпечення адекватності при описі функціонування сучасних мережеємних систем-систем ОВТ; розробка системи показників, заснованих на використанні рівнянь Ланчестера, для аналітичної оцінки ефективності бойового застосування датацентричних ЗРС.

\section{Виклад основного матеріалу}

1. Аналіз існуючої моделі OODA.

Починаючи розгляд питань використання петлі OODA в рамках концепту метаморфізму датацентричних систем-систем слід зазначити відповідність петлі Бойда загальній методології наукового методу: спостереження - формування гіпотези - перевірка гіпотези - побудова теорії, яка відповідає даним спостереженням. Науковий метод служить для перевірки теорії на відповідність експериментів

і використовує експерименти для формування нових теорій або коригування існуючих.

Розглянемо більш детально кожен 3 чотирьох окремих елементів зазначеної петлі.

Модель збройної боротьби двох протиборчих сторін, з урахуванням циклів Дж. Бойда (OODA), побудована на основі матеріалів робіт $[9$, С. $16 ; 10$, С. 52],приведена на рис. 1.

Спостереження (observation) - це процес збору інформації, необхідної для прийняття рішення в даному конкретному випадку. Необхідна інформація може бути отримана як від зовнішніх, так і від внутрішніх джерел. Під внутрішніми джерелами інформації розуміються елементи зворотного зв'язку петлі. В якості зовнішніх використовуються датчики, а також інші канали отримання інформації.

Орієнтація (orientation) - найбільш відповідальний і найбільш складний з когнітивної точки зору етап у всьому циклі OODA. Цю думку Дж. Бойд неодноразово підкреслював у своїх виступах. Етап орієнтації складається з двох під етапів: руйнування (destruction) і творення (creation).
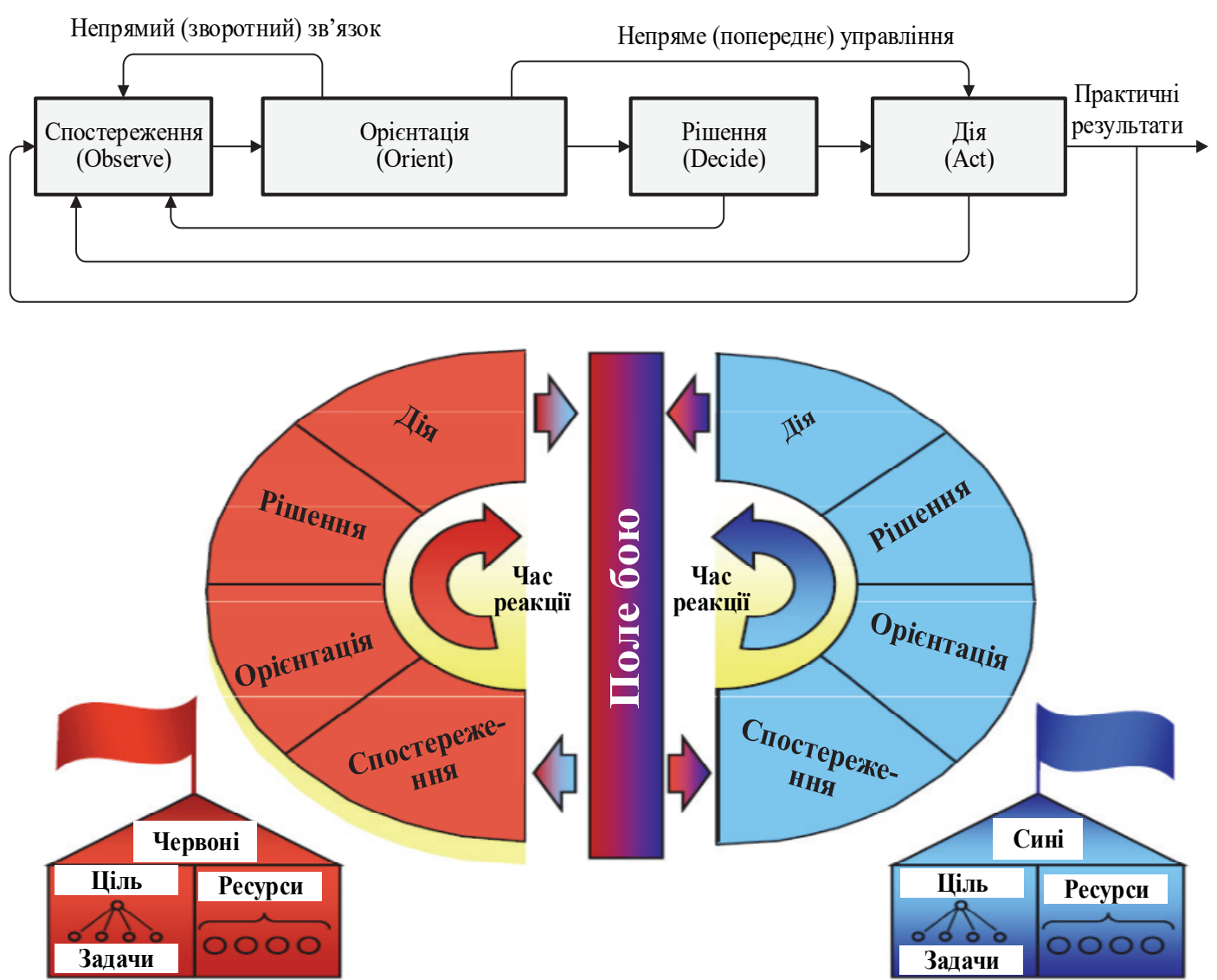

Рис. 1. Модель збройної боротьби двох протиборчих сторін з урахуванням циклів Дж. Бойда (OODA) Джерело: розроблено автором за даними [9, С. 16; 10, С. 52].

Існуюче класичне ієрархічне управління визначається саме цим. Так як людина не має можливості швидко обробляти інформацію, загальний обсяг інформації розбивається (destruction) за рівнями управління. Крім того, руйнування передбачає розбиття ситуації на дрібні елементарні частини, які більш легкі для розуміння. Особи, які приймають рішення (ОПР), будуть прагнути розчленувати або 
декомпозувати завдання до такого рівня, поки новоутворені складові завдання стають близькими до стандартних або типових ситуацій, для яких у особи, що приймає рішення (ОПР), є план вирішення. ОПР просто ідентифікує поточну ситуацію по відношенню до тих, з якими він знайомий, і застосовує заздалегідь заготовлений план дій для цієї підзадачі. Потім ці складові елементарні підплани об'єднуються в загальний план дій, що і відповідає фазі “творення”. Якщо немає реальних планів, з числа яких може бути вибрано рішення, то процес залишається на етапі орієнтації і здійснюється подальша декомпозиція задачі.

Ухвалення рішення (decision) - третій етап циклу OODA. Якщо до цього етапу ОПР змогла сформувати тільки один реальний план, то просто приймається рішення - виконувати цей план чи ні. Якщо ж сформовані кілька альтернативних варіантів дій, то ОПР на даному етапі здійснює вибір найкращого з них для подальшої реалізації. Вибір найкра- щого плану може здійснюватися за критерієм ефективність - вартість. В умовах ліміту часу найкращий план той, який відповідає вимогам швидкості і надійності.

Дія (action) - заключний етап циклу, що передбачає практичну реалізацію обраного курсу дій або плану. Дія передбачає видачу наказу або вказівки, фізичну атаку, активний захист, переміщення в просторі або управління датчиками з метою поліпшення спостереження в наступному бойовому циклі.

2. Модель формування циклу бойової роботи ЗРС на основі використання модифікованої петлі OODA (циклу Бойда).

На рис. 2 приведена модель формування циклу бойової роботи ЗРС на основі використання модифікованої петлі OODSA (циклу Бойда).

Перш за все зазначимо, що протиповітряний бій як дата-центрична операція вимагає створення цільової системи, найкращим чином пристосованої для проведення даної операції в конкретних умовах.

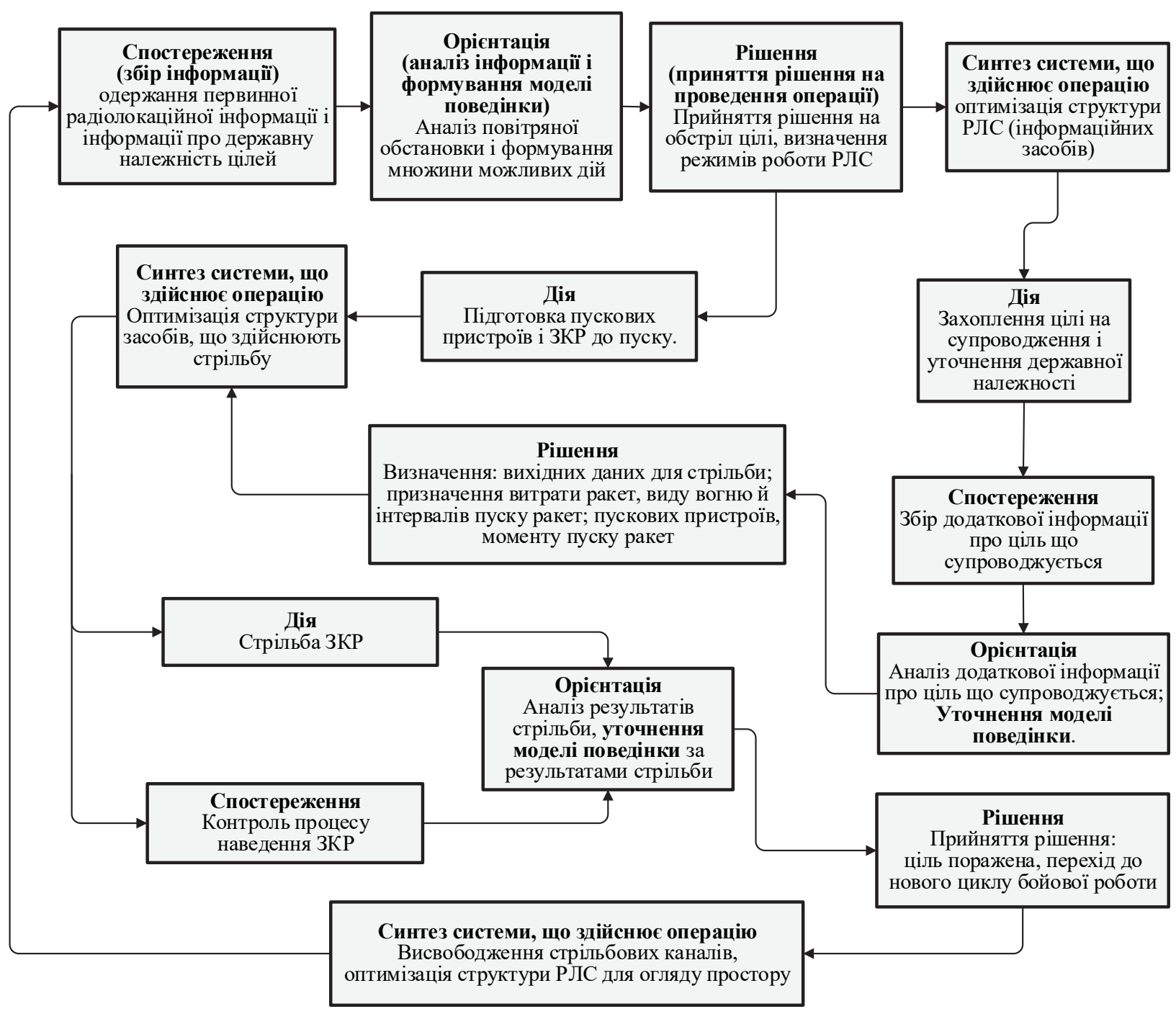

Рис. 2. Модель формування циклу бойової роботи ЗРС на основі використання модифікованої петлі OODSA Джерело: розроблено автором. 
Якщо раніше синтез цільової системи був можливий тільки при створенні системи зенітного ракетного прикриття, то тепер дата-центричні ЗРС наділяються здатністю динамічного синтезу своєї структури (метаморфізму). Таким чином “дія” (action) доповнюється новою фазою - “синтез" (synthesis). При цьому, фаза "орієнтація” (orientation) набуває дещо інше трактування. Тепер у залежності від етапу бойової роботи “орієнтація" може розглядатися як аналіз інформації, іiі структурування (перетворення в дані), або формування/уточнення моделі поведінки.

Прийняття "Рішення" - $\epsilon$ не свідомою ідеєю, а вольовим вибором, але здійснюваним в рамках обраної моделі поведінки (класична “ситуація вибору" полягає в неможливості аналітичного його рішення, а в необхідності саме командирського рішення).

Слід вказати на те, що тепер цикл бойової роботи ЗРС може бути розбитий на декілька окремих
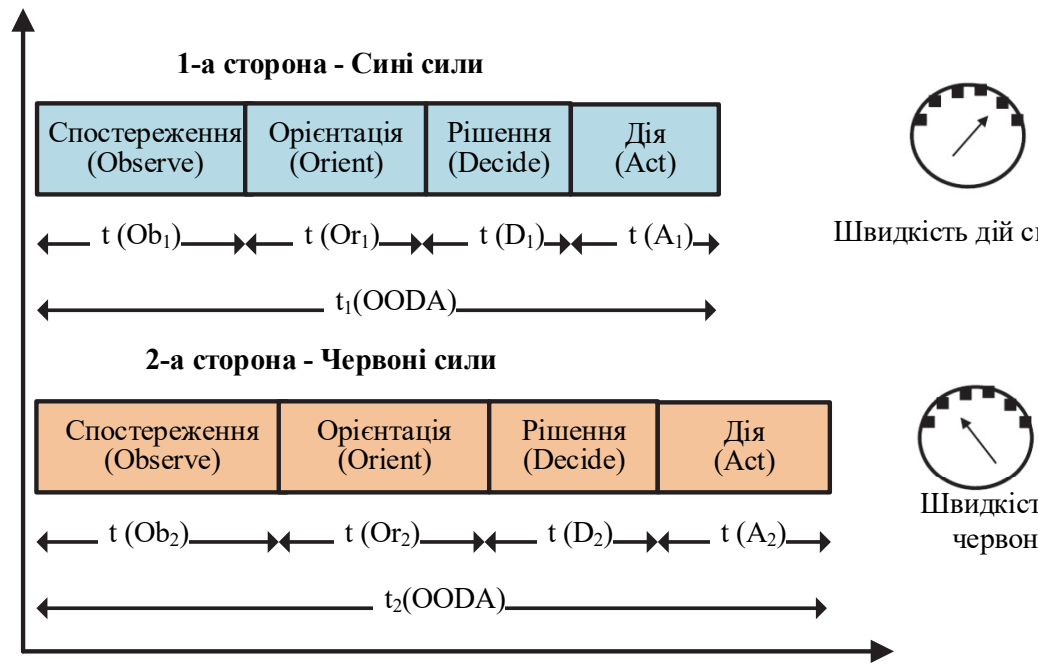

Швидкість дій синіх

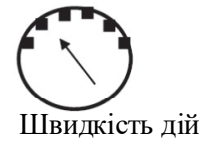

червоних

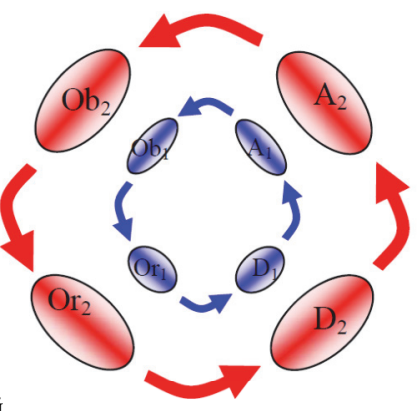

б)

a)

Рис. 3. Графічна інтерпретація часових співвідношень OODA-циклів для протиборчих сторін: а - швидкість дій визначає переможця в циклі Бойда; б - “сині” сили діють всередині циклу “червоних” сил

Джерело: розроблено автором за даними [9, С. 18].

Аналітична оцінка ефективності ППБ підрозділу озброєного ЗРС СД/ДД, що описується моделлю OODSA, може бути здійснена 3 використанням рівнянь Ланчестера приведених у роботах [11-12].

Розглянемо варіант протиповітряного бою який описується наступними умовами: $n_{u}-$ кількість

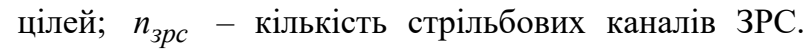
Введемо коефіцієнт складності ППБ як відношення:

$$
k_{c . П П Б}=\frac{n_{3 p c 0}}{n_{u 0}},
$$

де $n_{u 0}, n_{\text {зрс0 }}$ - відповідно кількість цілей і кількість стрільбових каналів ЗРС на початку ППБ.

Можливості бойових засобів ЗРС і ЗПКН, їх вогнева міць будуть характеризуватися ефективною скорострільністю [12]:

$$
\begin{aligned}
& \Lambda_{\text {зрс }}=P_{\text {зрс }} \cdot \Pi_{\text {зрс }}, \\
& \Lambda_{u}=P_{\text {зпкн }} \cdot \Pi_{\text {зпкн }},
\end{aligned}
$$

де $\Lambda_{\text {зрс }}, \Lambda_{u}$ - ефективні скорострільності ЗРС і засобів повітряно-космічного нападу; $P_{\text {зрс }}, P_{\text {зпкн }}-$ відповідно ймовірність ураження цілі за стрільбу для ЗРС і ЗПКН; $\Pi_{\text {зрс }}, \Pi_{\text {зикн }}$ - щільність вогню характеризується як кількість стрільб в хвилину, яка може бути реалізовано вогневими засобами ЗРС i ЗПКН.

Протиповітряний бій носить швидкоплинний характер, сторони діють відповідно до задуму, сформованому до початку бойових дій, відповідно швидкість, $з$ якою зменшуються сили протиборчих сто- 
рін, залежить від поточних значень їх чисельності та вогневої потужності. Зміна сил протиборчих сторін у ході ППБ може бути представлена у формі системи диференціальних рівнянь [11-12]:

$$
\begin{aligned}
& \frac{d n_{3 p c}}{d t}=f_{2}\left(n_{u}, n_{3 p c}, \ldots\right), \\
& \frac{d n_{u}}{d t}=f_{1}\left(n_{u}, n_{3 p c}, \ldots\right) .
\end{aligned}
$$

Рішення цих рівнянь у вигляді функцій $x(t)$ i $y(t)$ дає уявлення про результат бою. Математично це виглядає досить просто:

$$
\begin{aligned}
& \frac{d n_{3 p c}}{d t}=-\Lambda_{u_{u}} n_{u}, \\
& \frac{d n_{u}}{d t}=-\Lambda_{3 p c} n_{3 p c} .
\end{aligned}
$$

Отримані рівняння називають рівняннями Ланчестера, вони показують, як убуває число бойових засобів супротивників за час бою. В результаті інтегрування цих рівнянь виходить рівняння стану, так званий “квадратичний закон” Ланчестера:

$$
\Lambda_{u}\left(n_{u, 0}^{2}-n_{u}^{2}\right)=\Lambda_{\text {зрc }}\left(n_{3 p c 0}^{2}-n_{3 p c}^{2}\right) .
$$

Дане рівняння може бути перетворено до форми, яка б показала виснаження сил ЗРС і ЗПКН в залежності від початкового співвідношення сил і вогневих можливостей:

$$
\begin{aligned}
& n_{\text {зрс }}(t)=\frac{1}{2}\left(\left(n_{3 p c 0}-k_{в e} n_{u 0}\right) e^{k_{i} t}+\left(n_{3 p c 0}+k_{в e} n_{u 0}\right) e^{-k_{i} t}\right), \\
& n_{u}(t)=\frac{1}{2}\left(\left(n_{u 0}-k_{B e}^{-1} n_{3 p c 0}\right) e^{k_{i} t}+\left(n_{u 0}+k_{B e}^{-1} n_{3 p c 0}\right) e^{-k_{i} t}\right),
\end{aligned}
$$

де $k_{i}=\sqrt{\Lambda_{\text {зрс }} \cdot \Lambda_{u}}-$ показник інтенсивності ППБ;

$$
k_{\text {вe }}=\sqrt{\Lambda_{u} / \Lambda_{\text {зрс }}}-\text { показник відносної ефекти- }
$$
вності ЗРС у протиповітряному бою.

На рис. 4 наведено приклад розрахунку втрат ЗРС і ЗПКН у протиповітряному бою. У прикладі розглядається ситуація: 60 тактичних літаків наносять удар по ЗРС, у складі якої можливе формування

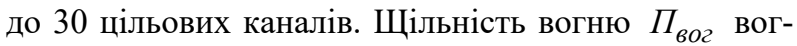
невих засобів як для ЗРС так і для ЗПКН будемо розглядати у залежності від середнього часу циклу стрільби $\left(t_{u c}\right)$ :

$$
\Pi_{B O 2}=\frac{1}{t_{u p c}} .
$$

Варіант А (рис. 4) сторони мають однакову ефективну скорострільність $\Lambda_{\text {зрс }}=\Lambda_{u}=0,4$ ц/хв.

Варіант Б (рис. 4) ЗРС має перевагу у ефективній скорострільності: $\Lambda_{u}=0,3$ ц/хв., $\Lambda_{\text {зрс }}=0,5$ ц/хв.

Можна показати, що при описі протиповітряного бою квадратичною функцією Ланчестера, ППБ буде виграний ЗРС, якщо і тільки якщо:

$$
k_{\text {с.ППБ }}>k_{\text {ве }} \text {. }
$$

Як бачимо показники ефективної скорострільності у більшому ступеню ніж чисельність впливають на результати ведення протиповітряного бою, а модель, побудована з їх використанням, більш точно описує хід і результати ППБ, ніж модель Бойда, що спирається тільки на часові показники.

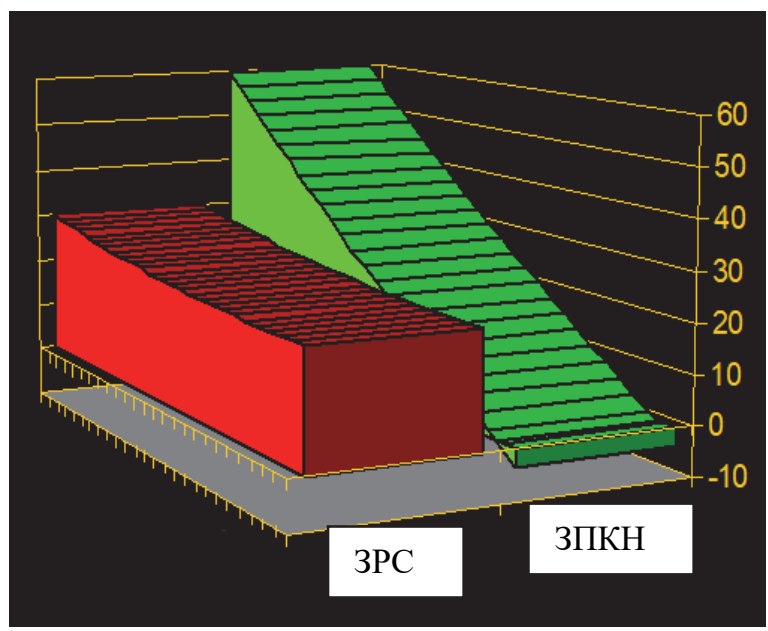

Варіант Б

Варіант A

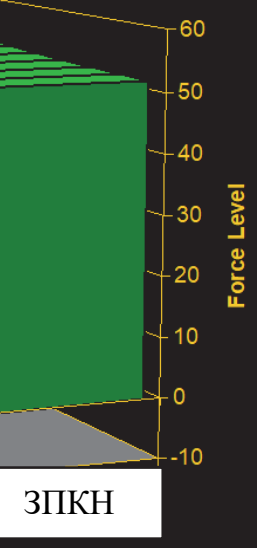

Рис. 4. Приклад розрахунку втрат ЗРС і ЗПКН у протиповітряному бою
Введемо показник виживання ЗРС у протиповітряному бою, який може бути описаний як відношення кількості стрільбових каналів ЗРС в кінці ППБ $n_{\text {зрсf }}$ до їх кількості на початку бою (у разі перемоги в ППБ):

$$
k_{\text {виж. } 3 p c}=\frac{n_{\text {зрсf }}}{n_{\text {зрс } 0}}=\sqrt{1-k_{\text {вe }}^{2} k_{c . П П Б}^{-2}},
$$

де $k_{\text {виж.зрс }}-$ показник втрат ЗПКН.

У разі, якщо в ударі бере участь пілотована аві- 
ація, як правило існує рівень втрат, при якому супротивник відмовляється від подальшого нанесення удару. У такому випадку час протиповітряного бою

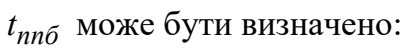

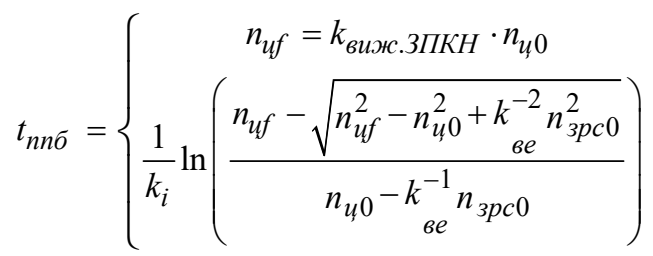

де $k_{\text {виж.ЗПкН }}-$ коефіцієнт виживання ЗПКН:

$$
0 \leq k_{\text {виж. } 3 П к Н} \leq 1 \text {. }
$$

Підставляючи знайдений час $t_{n n б}$ в (5) визначимо виснаження сил ЗРС $x_{f}$. 3 урахуванням (8) необхідно скорегувати умову виграшу ППБ для ЗРС (10):

$$
k_{c . П \Pi Б}>\frac{k_{\text {вe }}}{n_{u f}} \cdot \sqrt{\left(\frac{n_{u 0}^{2}-n_{u f}^{2}}{\left(1-k_{\text {виж. } 3 \text { РС }}^{2}\right)}\right)} .
$$

Рівняння (7) - (8) відповідають випадку, коли ЗРС протидіє ударній групі ЗПКН. Досить часто має місце ситуація, коли ЗПКН здійснюють груповий удар, причому щільність потоку цілей визначається щільністю нальоту:

$$
\lambda_{\text {зикн }}=\frac{N_{2 p}}{\Delta t},
$$

де $N_{z p}, \Delta t$ - відповідно кількість цілей у групі і інтервал між групами ЗПКН у нальоті.

Аналогічно по мірі руху цілей у дію починають вступати вогневі канали малої дальності і близької діï, що також можна розглядати як поповнення сил ЗРС $з$ інтенсивністю $\lambda_{\text {зрс }}$ У У такому разі рівняння (5) можна представити як:

$$
\begin{aligned}
& \frac{d n_{3 р c}}{d t}=-\Lambda_{u} n_{u}+\lambda_{3 р c}, \\
& \frac{d n_{u}}{d t}=-\Lambda_{\text {зрс }} n_{\text {зрс }}+\lambda_{\text {зикн }} .
\end{aligned}
$$

У загальному випадку темпи поповнення сил можуть бути як постійними, так і змінними. Рішення системи рівнянь (15) дає змогу проаналізувати процес ППБ. В окремому випадку, коли темпи поповнення сил постійні, рішення системи рівнянь (15) буде мати вид [12]:

$$
\begin{aligned}
& n_{\text {зрс }}=\frac{1}{2}\left(n_{\text {зрс } 0}-\frac{\lambda_{\text {зикн }}}{\Lambda_{\text {зрс }}}\right) \cdot \operatorname{ch}\left(k_{i} \cdot t\right)+ \\
& +\frac{\lambda_{\text {зрс }}-\Lambda_{u} n_{u 0}}{2 k_{i}} \cdot \operatorname{sh}\left(k_{i} \cdot t\right)+\frac{\lambda_{\text {зикн }}}{\Lambda_{\text {зрс }}}, \\
& n_{u}=\frac{1}{2}\left(n_{u 0}-\frac{\lambda_{3 p c}}{\Lambda_{u}}\right) \cdot \operatorname{ch}\left(k_{i} \cdot t\right)+ \\
& +\frac{\lambda_{\text {зикн }}-\Lambda_{\text {зрс }} n_{\text {зрс } 0}}{2 k_{i}} \cdot \operatorname{sh}\left(k_{i} \cdot t\right)+\frac{\lambda_{\text {зрс }}}{\Lambda_{u}},
\end{aligned}
$$

де $c h, s h$ - відповідно гіперболічні косинус і синус.

\section{Висновки}

Зміна парадигми розвитку систем ОВТ, розбудова теорії дата-центричних операцій призвели до виникнення нового класу систем - дата-центричні системи-систем, які набули нову властивість - динамічний синтез своєї структури. Перестройка структури DSoS здійснюється 3 використанням методу адаптивного просторово-часового синтезу. Це призвело до того, що існуюча модель OODA стала неадекватною реальним процесам бойового протиборства систем. Адекватність досягається у рамках використання моделі OODSA і переході до застосування показників якості DSoS, розроблюваних на базі рівнянь Ланчестера, що забезпечує заміну часової оцінки якості процесу протиповітряного бою ЗРС на імовірностно-часову оцінку. Однак слід зауважити, що рівняння Ланчестера неможливо застосовувати при оцінці фінальної стадії бою, на етапі “виснаження" сторін.

\section{Список літератури}

1. Скорик А.Б. Еволюційний розвиток концепції мережево-центричних війн, системно-концептуальні основи теорії дата-центричних операцій / А.Б. Скорик, С.П. Ярош // Збірник наукових праць Харківського національного університету Повітряних Сил. - 2020. - № 4(66). - С. 26-34. https://doi.org/10.30748/zhups.2020.66.03.

2. Скорик А.Б. Вплив руйнівних технологій на розвиток архітектури C4ISR систем. Концептуальні основи побудови архітектури дата-центричної системи-систем / А.Б. Скорик, С.П. Ярош, Д.О. Меленті // Системи озброєння і військова техніка. - 2020. - № 4(64). - С. 107-119. https://doi.org/10.30748/soivt.2020.64.14.

3. Дата-центрична операція, принципи системо-системного мислення і концепція створення архітектурного фреймворку зенітних ракетних систем AFADS / А.Б. Скорик // Системи обробки інформації. - 2020. - № 4(163). - С. 77-86. https://doi.org/10.30748/soi.2020.163.08.

4. Boyd J. A Discourse on Winning and Losing [Електронний ресурс] / J. Boyd. - 2018. - Режим доступу: https://www.coljohnboyd.com/static/documents/2018-03_Boyd_John_R_edited_Hammond_Grant_T_A_Discourse_on_ Winning_and_Losing.pdf.

5. Jamieson V. An ISR Perspective on Fusion Warfare / V. Jamieson, M. Calabrese // The Mitchell Institute for Aerospace Studies. - Arlington, VA, USA, October 2015. - P. 9. 
6. Restoring America's military competitiveness: Mosaic Warfare / D. Deptula, H. Penney, M. Lawrence, A. Stutzriem, M. Gunzinger // The Mitchell Institute for Aerospace Studies. - Arlington, VA, USA, September 2019. - P. 59.

7. Révay M. OODA Loop in Command \& Control Systems / M. Révay, Miroslav Líška // Communication and Information Technologies (KIT) IEEE International Conferences. - Vysoke Tatry, Slovakia, Oct. 4-6, 2017. https://doi.org/10.23919/KIT.2017.8109463.

8. Air Power Development Centre F3-G, Department of Defence. 5th Generation Air C2 and ISR. - Canberra BC 2610, Australia, 2017. -94 p.

9. Ивлев А.А. Основы теории Бойда. Направления развития, применения и реализации: монография / А.А. Ивлев. Москва, 2008. - 64 с.

10. Теорія прийняття рішень органами військового управління: монографія / За ред. В.І. Ткаченка, С.Б. Смірнова. - Х.: ХУПС, 2008. - $545 \mathrm{c}$.

11. Southard L. The Lanchester Equations of Warfare [Електронний ресурс] / L. Southard. - 2015. - Режим доступу: https://slideplayer.com/slide/4501313/.

12. Ануреев И.И. Применение математических методов в военном деле / И.И. Ануреев, А.Е. Татарченко. - М.: Военное издательство, 1967. -243 с.

Надійшла до редколегї 22.02.2021

Схвалена до друку 16.03.2021

Відомості про автора:

Скорик Анатолій Борисович кандидат технічних наук доцент доцент кафедри Харківського національного університету Повітряних Сил ім. І. Кожедуба, Харків, Україна

https://orcid.org/0000-0002-4327-8796

\section{Information about the author:}

Anatolii Skoryk

Candidate of Technical Sciences Associate Professor

Senior Lecturer of Ivan Kozhedub Kharkiv

National Air Force University,

Kharkiv, Ukraine

https://orcid.org/0000-0002-4327-8796

\title{
МЕТОД АДАПТИВНОГО ПРОСТРАНСТВЕННО-ВРЕМЕННОГО СИНТЕЗА СТРУКТУРЫ ДАТА-ЦЕНТРИЧЕСКОЙ ЗРС. МОДЕЛЬ ЦИКЛА БОЕВОЙ РАБОТЫ ЗРС НА ОСНОВЕ ИСПОЛЬЗОВАНИЯ МОДИФИЦИРОВАННОЙ ПЕТЛИ ООDА
}

\author{
А.Б. Скорик
}

B статье поднимаются вопросы развития теории дата-центрических операций (DCO) на основе разработки метода адаптивного пространственно-временного синтеза структуры дата-центрической ЗРС. Данный метод рассматривается как форма реализации главных концептов DCO: метаморфизма и 4D экстенционализма датацентрических систем-систем. Предлагается при описании боевой работы ЗРС использовать модифичированную модель петли ООDА. Модификация осуществляется путем введения фазы синтеза и изменения содержания фазы "ориентация". Цикл боевой работы дата-центрической ЗРС представляется как последовательность вложенных петель OODSA. Рассматривается методика использования уравнений Ланчестера для аналитической оценки эффективности боевого применения ЗРС.

Ключевые слова: Дж. Бойд, ЗРС, метаморфизм, уравнение Ланчестера, оценка эффективности, системасистем, теория дата-центрической операции, цикл боевой работы, 4D экстенционализм, OODA, OODSA.

\section{METHOD OF ADAPTIVE DIMENSIONAL-TIME SYNTHESIS OF ADS DATE-CENTRIC STRUCTURE. MODEL CYCLE COMBAT OPERATION ADS BASED ON THE USE OF MODIFIED LOOP OODA}

\author{
A. Skoryk
}

The article discusses questions about the development of the theory of data-centric operations (DCO). The DCO theory is based on the concepts of metamorphism - variability \& agile development and 4D-extensionalism of data-centric systems. Metamorphism means adaptive dimensional -time synthesis and reconfiguration of the data-centric system structure (DSoS), which provides the most efficient DSoS operation in specific conditions. One of the main issues in the development of the method of adaptive dimensional -time synthesis of the structure of data-centric ADS is considered the development of the model of the cycle of combat work. The model to be developed is based on J. Boyd's concept and his model of the collective struggle of two opposing sides, taking into account the cyclic processes OODA - Observe - Orient - Decide - Act. The work analyzes the components of the OODA processes.

The article proposes to use a modified OODA loop model when describing the combat performance of ADS. The modification is done by introducing a synthesis phase and changing the content of the "orientation" phase. The combat operation cycle of a data-centric ADS is presented as a sequence of nested loops OODSA - Observe - Orient - Decide - Synthesis - Act. This work considers the OODSA model for data-centric ADS. The notion of "orientation" has been substantially changed. Now, depending on the stage of the battlefield operation, "orientation" can be regarded as analysis of information, its structuring (conversion into data), or formation/refinement of a behavioral model. Decision making is regarded as a voluntary choice to be made within the framework of the reverse behavioral model. The article discusses the methodology of using the Lanchester equations to analytically assess the effectiveness of the combat use of ADS. The key variable that determines the overpowering or defeat in the classical OODA loop is "time. Within the framework of OODSA model the performance of the process of anti-aircraft warfare ADS is evaluated using Probabilistic-time indicators.

Keywords: J. Boyd, ADS, metamorphism, Lanchester equation, performance evaluation, system-systems, data-centric operation theory, combat cycle, $4 D$ extensionalism, OODA, OODSA. 